\title{
Optimization and Characterization Freeze Dried Fish Protein Hydrolysate Production
}

\author{
Sasithorn Kongruang ${ }^{1, *}$, Nicharee Wisuthiphaet ${ }^{1}$ \\ ${ }^{1}$ Bioprocess Engineering and Biotechnology Center, Department of Biotechnology, Faculty of Applied Science, King Mongkut's \\ University of Technology North Bangkok, Bangkok, 10800, Thailand
}

\begin{abstract}
The production of fish protein hydrolysate from underutilized fish species is attracting the industrial interest for increasing the rich protein values. The central composite design was used to optimize the degree of enzymatic hydrolysis of freeze-dried fish protein hydrolysate (FPH) production by the application of commercial Alcalase on the recovery mixed small fish protein. The effects of time, temperature, $\mathrm{pH}$ and enzyme concentration on the degree of hydrolysis $(\mathrm{DH})$ of five strains of fish as Rastrelliger brachysoma (short-bodied mackerel), Rastrelliger kanagurta (Indian mackerel), Leiognathidae (Ponyfish), Amblygaster leiogaster (Smooth belly sardinella) and Selaroides leptolepis (yellow-stripe scad) were experimented. Result showed that the FSH production was optimized at $2.85 \% \mathrm{v} / \mathrm{w}$ enzyme concentration at $61^{\circ} \mathrm{C}, \mathrm{pH} 8.50$ for $27 \mathrm{~min}$ with $89.42 \% \mathrm{DH}$. Mathematical model was proposed and validated under the optimum condition. The high proportion $(46.43 \%)$ of smaller molecular weight $<1 \mathrm{kDa}$ was found in hydrolysate. Freeze-dried fish protein hydrolysate was produced and revealed that three predominant amino acids as glutamine, lysine and alanine. Based on amino acid compositions, the waste fish hydrolysate showed nutritional value and high potential for the applications of feed supplementation.
\end{abstract}

Keyword. Fish hydrolysate, Enzyme hydrolysis, Alcalase, Response surface methodology

\section{Introduction}

The fishery industries have been substantially increasing in catching because of the continuously increasing demand of the protein derived product to 463.8 million tons by 2050 [1]. To secure the sustainable economic impact and meet the competition of the world markets, there is a requirement to derive the fishery waste into valuable protein source of products through fish protein hydrolysate (FPH) production. As a great of the market size, the discard of rich dark muscle of small fishes has a potential to add up this demand. Hence, utilization by transformation of these rich proteins into protein hydrolysate produces highly valuable products. Several fish species mostly from North Atlantic and Pacific Ocean have studied for protein hydrolysates [2-4]; however, the related work in discard fish hydrolysate rarely reported in the fish species in tropical waters of Indo-West Pacific region. FPH plays an important role in the human and animal diet as a nutritional quality and functional food with highly digestible peptide and protein. This functional protein has used in many food applications such as emulsion properties, water holding capacity, fat absorption and foaming ability [2-8]. Moreover, bioactive properties of FSH also well known as antioxidant, antiproliferate activity and antihypertensive activity [9]. The choice of using these enzymes either endoproteinase, exoproteinase or the mixture of both is the crucial factor as the main activity with specificity toward the substrate resulting in the amino acid sequence of peptides or amino acid residues that lead to different bioactive, functional and nutritional properties in the hydrolysates [9-14]. Among these hydrolyzing enzymes, Alcalase (EC 3.4.21.62) is an approved food grade endopeptidase and a highly efficient bacterial protease from Bacillus licheniformis. This enzyme has developed for the hydrolysis of all kinds of proteins with the optimum temperature range between 55 and $70^{\circ} \mathrm{C}$, depending on the specific substrate and $\mathrm{pH}$ values between 6.5 and 8.5 [15]. The process parameters for production FPH involve on several factors including enzyme to substrate ratio, $\mathrm{pH}$, time and temperature, while the response variables were degree of hydrolysis and protein yield [16-22]. Since production optimization using a one factor at a time is not effective and not include the interactions among effecting parameters, experimental design as statistical completely central composite by response surface methodology has to apply to the degree of hydrolysis in order to find the appropriate enzyme concentration, hydrolysis time, hydrolysis temperature and $\mathrm{pH}$. The final aim was to provide the alternative processes to reduce the production cost depend upon the availability of operation. Comparison of amino acid content from amino acid profile of FSH was also determined.

\section{Materials and methods}

\subsection{Enzyme}

The enzymatic hydrolysis from bacterial protease from Bacillus licheniformis was carried out using a commercial protease, Alcalase ${ }^{\circledR 2} 2.4$ L (Activity $=2.59$

* Corresponding author: wanticha.s@agro.kmutnb.ac.th 
U.mL ${ }^{-1}$; EC 3.4.21.14) was obtained from EMD Millipore, USA and stored at $4^{\circ} \mathrm{C}$ until used. HPLC grade acetonitrile, chloroform and acetone were supplied by Fisher Scientific. All other chemicals used analytical grade.

\subsection{Substrate}

Five fish strains as Rastrelliger brachysoma (shortbodied mackerel), Rastrelliger kanagurta (Indian mackerel), Leiognathidae (Ponyfish), Amblygaster leiogaster (Smooth belly sardinella) and Selaroides leptolepis (yellow-stripe scad) were provided by animal feed company, INTEQC Group., Co Ltd, Thailand. Equal proportion of fish was washed, minced to homogenous paste $(<3 \mathrm{~mm}$ in size) and then placed in plastic bags immediately after process. These $100 \mathrm{~g}$ of samples was stored in $-20{ }^{0} \mathrm{C}$ individually until further use.

\subsection{Proximate chemical analysis}

The chemical compositions of mixed fish samples and FPH were determined according to Association of Official Analytical Chemists (AOAC, 1990). All experiments performed in triplicate.

\subsection{Enzymatic hydrolysis}

Each experiment run was carried out $10 \mathrm{~g}$ of samples were thawed at room temperature and adjusted $\mathrm{pH}$ 4-12 according the experiment plan in $250 \mathrm{~mL}$ Erlenmeyer flask. Samples were then adjusted the final volume to 30 $\mathrm{mL}$ and incubated in shaking incubator at desired temperature from $40-80{ }^{\circ} \mathrm{C}$ at $200 \mathrm{rpm}$ for the reaction times from 0-40 min. Different concentrations of Alcalase were added at $1-5 \% \mathrm{v} / \mathrm{w}$ during the control hydrolysis reaction temperature. To stop the reaction, the mixtures were stopped at $85{ }^{0} \mathrm{C}$ for 5 minutes. The samples were then transferred to microcentrifuge tube after centrifuged at $12,000 \mathrm{rpm}$ for $15 \mathrm{~min}$ for analytical analysis.

\subsection{Central composite design}

The chosen parameters on FPH were evaluated using response surface methodology (RSM). The Central Composite Statistical Design (CCD) was carried out the statistical model for the individual and interactive the effects of time $(0-40 \mathrm{~min})$, temperature $\left(40-80^{\circ} \mathrm{C}\right), \mathrm{pH}$ (4-12) and enzyme concentration $(1-5 \% \mathrm{v} / \mathrm{w})$ on the degree of hydrolysis. Levels of these factors were optimized for maximum degree of hydrolysis (the response) according to Table 1. All the 30-trial experiments were investigated in triplicate. Degree of hydrolysis was determined as the response for the combination of the reaction effects given in Table 2 . The regression analysis of data obtained on degree of hydrolysis was chosen as quadratic model by equations of the following form:

$$
y_{1}=\beta_{0}+\sum_{i=1}^{4} \beta_{i} X_{i}+\sum_{i=1}^{4} \sum_{j=1}^{4} \beta_{i j} X_{i} X_{j}+\sum_{i=1}^{4} \beta_{i i} X_{i}^{2}
$$

Here, $\mathrm{X}_{1}, \mathrm{X}_{2}, \mathrm{X}_{3}, \mathrm{X}_{4}$, are the parameter values for the independent variables (time, temperature, $\mathrm{pH}$, enzyme concentration) as described in Table 2 . The constants $\beta_{0}, \beta_{\mathrm{i}}$, and $\beta_{\mathrm{ij}}(\mathrm{i}, \mathrm{j}=1,2,3,4)$ are coefficient estimates for degree of hydrolysis $\left(y_{1}\right)$, where $\beta_{0}$ is an intercept term, $\beta_{\mathrm{i}}$ are linear terms, $\beta_{\mathrm{ii}}$ are quadratic terms, and $\beta_{\mathrm{ij}}$ are interaction terms. The accuracy and general suitability of the above polynomial model was evaluated by the coefficient of determination $\left(R^{2}\right)$. The experimental data was analyzed using the statistical software, Design-Expert software version 8.0.6 (STATEASE Inc., Minneapolis, MN, USA)

Table1. Levels of factor for fish protein hydrolysis production.

\begin{tabular}{|l|c|c|c|c|c|}
\hline \multirow{2}{*}{ Factor } & \multicolumn{5}{|c|}{ Level } \\
\cline { 2 - 6 } & 1 & 2 & 3 & 4 & 5 \\
\hline A: Time (min) & 0 & 10 & 20 & 30 & 40 \\
\hline B: Temp $\left({ }^{0} \mathrm{C}\right)$ & 40 & 50 & 60 & 70 & 80 \\
\hline C: $\mathrm{pH}$ & 4 & 6 & 8 & 10 & 12 \\
\hline $\begin{array}{l}\text { D: Concentration } \\
(\% \text { v/w })\end{array}$ & 1 & 2 & 3 & 4 & 5 \\
\hline
\end{tabular}

\subsection{Degree of hydrolysis}

DH of FPH was analyzed for the content of $\alpha$-amino acid from the supernatant of each hydrolysis run according to Adler-Nissan, 1979 [23]. The degree of hydrolysis calculation reported according to equation 2 .

$$
\mathrm{DH}=\left[\left(\mathrm{L}_{\mathrm{t}}-\mathrm{L}_{0}\right) /\left(\mathrm{L}_{\max }-\mathrm{L}_{0}\right)\right] \times 100
$$

\subsection{Molecular distribution of FPH}

The supernatant of FPH was subjected to sequentially ultramembrane filtration by using a series of membranes (Centrifugal Devices, PALL Corporation, USA) from $100,30,10,5,3$ and $1 \mathrm{kDa}$, respectively. Fractions of hydrolysate separation were centrifuged at 2,000 g-force for $5 \mathrm{~min}$. to obtain both retentate and permeate. Both fractions were collected and measured its protein concentration by Nanodrop (Optizen NANOQ, Mecasys Co., Ltd, Korea).

\subsection{Amino acid composition analysis}

Chromatographic conditions of the HPLC system consisted of 626 pump, a 727 autosampler, 600S controller (Waters, MA), and a scanning fluorescence detector (Hewlett Packard), Millinnium ${ }^{\mathrm{TM}} 2010$ were used to determine the amino acid profile. The amino acid composition and chemical score of amino acid composition were previously calculated [24].

\subsection{Statistical analysis}

All data were expressed as mean \pm SD for all experiment. ANOVA was used to determine the significance of each term in the fitted equation. A $p$ value less than 0.05 was considered statistically significant. 


\section{Results and discussion}

\subsection{Degree of hydrolysis}

The influential parameters including time, temperature, $\mathrm{pH}$ and enzyme concentration on the Alcalase hydrolysis to $\mathrm{DH}$ were determined using $\mathrm{CCD}$ as described on the previous section. The design matrix of all the independent variables and the result of 30 runs in triplicate on DH are exhibited in Table 2. The observed results found $\mathrm{DH}$ in the range of $0 \%$ to $95.38 \%$. The highest observed condition for the DH of $95.38 \%$ was found at $60{ }^{0} \mathrm{C}, \quad \mathrm{pH} \quad 8.0$ with $3 \%$ v/w enzyme concentration over $40 \mathrm{~min}$. The quadratic term for hydrolysis temperature was found highly significant affecting DH $(p<0.0001)$ followed by $\mathrm{pH}$ with $p$-value of 0.0019 as shown in the ANOVA (Table 3).

Table 2. Actual levels of Alcalase hydrolysis conditions along with the observed values for the response variable, degree of hydrolysis.

\begin{tabular}{|c|c|c|c|c|c|}
\hline Run & $\begin{array}{l}\text { Time } \\
(\min )\end{array}$ & $\begin{array}{l}\text { Temp. } \\
\left({ }^{0} \mathrm{C}\right)\end{array}$ & $\mathrm{pH}$ & $\begin{array}{l}\text { Conc. } \\
(\% \mathrm{v} / \mathrm{w})\end{array}$ & $\mathrm{DH}$ \\
\hline 1 & 30 & 70 & 6 & 2 & $64.04 \pm 4.62$ \\
\hline 2 & 30 & 70 & 10 & 2 & $69.62 \pm 6.40$ \\
\hline 3 & 20 & 60 & 4 & 3 & $32.5 \pm 1.90$ \\
\hline 4 & 30 & 50 & 6 & 2 & $35.96 \pm 1.28$ \\
\hline 5 & 20 & 60 & 8 & 3 & $82.88 \pm 1.17$ \\
\hline 6 & 20 & 80 & 8 & 3 & $8.85 \pm 4.89$ \\
\hline 7 & 0 & 60 & 8 & 3 & 0 \\
\hline 8 & 20 & 60 & 8 & 1 & $86.92 \pm 0.74$ \\
\hline 9 & 20 & 60 & 8 & 5 & $84.81 \pm 0.09$ \\
\hline 10 & 40 & 60 & 8 & 3 & $95.38 \pm 1.68$ \\
\hline 11 & 20 & 60 & 8 & 3 & $82.12 \pm 5.40$ \\
\hline 12 & 20 & 60 & 8 & 3 & $83.46 \pm 2.14$ \\
\hline 13 & 10 & 70 & 6 & 2 & $46.15 \pm 6.04$ \\
\hline 14 & 30 & 70 & 10 & 4 & $66.54 \pm 2.06$ \\
\hline 15 & 20 & 60 & 8 & 3 & $82.69 \pm 2.03$ \\
\hline 16 & 30 & 50 & 6 & 4 & $49.23 \pm 2.69$ \\
\hline 17 & 10 & 50 & 10 & 4 & $53.46 \pm 1.54$ \\
\hline 18 & 10 & 50 & 6 & 2 & $33.46 \pm 0.62$ \\
\hline 19 & 10 & 70 & 6 & 4 & $56.15 \pm 3.08$ \\
\hline 20 & 30 & 70 & 6 & 4 & $65.38 \pm 3.81$ \\
\hline 21 & 20 & 60 & 8 & 3 & $81.92 \pm 0.78$ \\
\hline 22 & 10 & 70 & 10 & 4 & $51.54 \pm 0.99$ \\
\hline 23 & 30 & 50 & 10 & 2 & $56.15 \pm 0.38$ \\
\hline 24 & 20 & 60 & 8 & 3 & $82.31 \pm 0.54$ \\
\hline 25 & 10 & 50 & 6 & 4 & $25.00 \pm 0.59$ \\
\hline 26 & 20 & 40 & 8 & 3 & $25.00 \pm 4.35$ \\
\hline 27 & 30 & 50 & 10 & 4 & $62.69 \pm 0.40$ \\
\hline 28 & 10 & 50 & 10 & 2 & $59.62 \pm 0.44$ \\
\hline 29 & 10 & 70 & 10 & 2 & $51.54 \pm 2.31$ \\
\hline 30 & 20 & 60 & 12 & 3 & $52.69 \pm 2.17$ \\
\hline
\end{tabular}

However, $p$-values of hydrolysis time and enzyme concentration were insignificant ( $p=0.2569$ and 0.7740$)$. Results from the interaction terms between hydrolysis time and temperature, time and $\mathrm{pH}$, time and concentration were not significant with the $p$-values, $0.6065,0.7796$ and 0.6728 , respectively as well as other two interactions with temperature (Table 3). For the DH, the high coefficient of determination value $\left(R^{2}=0.8465\right)$ indicated that $84.65 \%$ of the variability in the response could be explained by the model. The independent and dependent variables were re-analyzed to obtain a real effect parameter model from regression equation that could predict the response within the given range. The regression equation for $\mathrm{DH}$ was reevaluated by the regression coefficient of linear, quadratic and interaction terms to fit a response surface model.

Table 3. ANOVA of enzymatic hydrolysis of fish protein affected by condition parameters for full quadratic equation.

\begin{tabular}{|c|c|c|c|c|c|}
\hline Source & $\begin{array}{c}\text { Sum of } \\
\text { Squares }\end{array}$ & $\begin{array}{c}\mathrm{d} \\
\mathrm{f}\end{array}$ & $\begin{array}{c}\text { Mean } \\
\text { Square }\end{array}$ & $\begin{array}{c}\mathrm{F} \\
\text { Value }\end{array}$ & $\begin{array}{c}p \text {-value } \\
\text { Prob }>\mathrm{F}\end{array}$ \\
\hline Model & $\begin{array}{c}14344.1 \\
2\end{array}$ & $\begin{array}{c}1 \\
4\end{array}$ & 1024.58 & 5.91 & 0.0008 \\
\hline A-Time & 240.93 & 1 & 240.93 & 1.39 & 0.2569 \\
\hline B-Temp & 5997.38 & 1 & 5997.38 & 34.58 & $<0.0001$ \\
\hline C-pH & 2437.11 & 1 & 2437.11 & 14.05 & 0.0019 \\
\hline $\begin{array}{c}\text { D- } \\
\text { concentr } \\
\text { ation }\end{array}$ & 14.82 & 1 & 14.82 & 0.085 & 0.7740 \\
\hline AB & 47.99 & 1 & 47.99 & 0.28 & 0.6065 \\
\hline AC & 14.08 & 1 & 14.08 & 0.081 & 0.7796 \\
\hline AD & 32.18 & 1 & 32.18 & 0.19 & 0.6728 \\
\hline BC & 407.54 & 1 & 407.54 & 2.35 & 0.1461 \\
\hline BD & 0.59 & 1 & 0.59 & $3.397 \mathrm{E}$ & 0.9543 \\
\hline CD & 22.21 & 1 & 22.21 & 0.13 & 0.7254 \\
\hline $\mathrm{A}^{2}$ & 1731.42 & 1 & 1731.42 & 9.98 & 0.0065 \\
\hline B ${ }^{2}$ & 6706.16 & 1 & 6706.16 & 38.67 & $<0.0001$ \\
\hline $\mathrm{C}^{2}$ & 2331.08 & 1 & 2331.08 & 13.44 & 0.0023 \\
\hline $\mathrm{D}^{2}$ & 70.10 & 1 & 70.10 & 0.40 & 0.5345 \\
\hline Residual & 2601.20 & 1 & 173.41 & & \\
\hline $\begin{array}{c}\text { Cor } \\
\text { Total }\end{array}$ & 16945.3 & 2 & & & \\
\hline
\end{tabular}

The resulting ANOVA for the reduced quadratic model (Table 4) summarizes the analysis of variance of each response and shows the significant model terms. The F-value of 11.57 implies that the model is significant (at $p<0.0001)$. Values of "Prob > F" ( $p$ values) less than 0.05 indicated that the model terms were significant. There is only a $0.01 \%$ chance that a "Model F Value" this large could occur due to noise. In this case hydrolysis temperature and $\mathrm{pH}$ were highly significant model terms with $p$-values of $<0.0001$ and 0.0003 . For the reduced model, we found $R^{2}=0.8726$ showing that the model gives a satisfactory fit to the experimental data. The following reduced quadratic model in terms of tested fermentation parameters was achieved as shown in equation (5).

$\mathrm{DH}=-840.53+(3.79 *$ Time $)+(20.97 * \mathrm{Temp})+(56.70 * \mathrm{pH})+$ $(0.02 *$ Time*Temp $)-(0.05 *$ Time*pH $)-(0.25 *$ Temp*pH $)-$

$\left(0.08 * \mathrm{Time}^{2}\right)-\left(0.16^{*} \mathrm{Temp}^{2}\right)-\left(2.36 * \mathrm{pH}^{2}\right)$ 
Table 4. ANOVA of enzymatic hydrolysis of fish protein affected by condition parameters for reduce quadratic equation.

\begin{tabular}{|c|c|c|c|c|c|}
\hline Source & $\begin{array}{c}\text { Sum of } \\
\text { Squares }\end{array}$ & df & $\begin{array}{c}\text { Mean } \\
\text { Square }\end{array}$ & F Value & $\begin{array}{c}p \text {-value } \\
\text { Prob > F }\end{array}$ \\
\hline Model & 1425.49 & 9 & 1579.5 & 11.57 & $<0.0001$ \\
\hline A-Time & 371.15 & 1 & 371.15 & 2.72 & 0.1148 \\
\hline B-Temp & 6836.00 & 1 & 6836.00 & 50.08 & $<0.0001$ \\
\hline C-pH & 2664.31 & 1 & 2664.31 & 19.52 & 0.0003 \\
\hline AB & 47.99 & 1 & 47.99 & 0.35 & 0.5599 \\
\hline AC & 14.08 & 1 & 14.08 & 0.10 & 0.7514 \\
\hline BC & 407.54 & 1 & 407.54 & 2.99 & 0.0994 \\
\hline $\mathrm{A}^{2}$ & 1870.56 & 1 & 1870.56 & 13.70 & 0.0014 \\
\hline $\mathrm{B}^{2}$ & 7047.31 & 1 & 7047.31 & 51.63 & $<0.0001$ \\
\hline $\mathrm{C}^{2}$ & 2499.01 & 1 & 2499.01 & 18.31 & 0.0004 \\
\hline Residual & 2729.82 & 20 & 136.49 & & \\
\hline Cor Total & 16945.31 & 29 & & & \\
\hline
\end{tabular}

Results found that DH of FSH production was significantly influenced by temperature and $\mathrm{pH}$. Our relationship of fish waste hydrolysis is well in agreement with the previous studies reported a quadratic model for production of protein hydrolysate [18, 25].

\subsection{Optimization of FSH condition}

From the optimization analysis of Alcalase hydrolysis to produce FPH, the suggested optimum levels of all the variables determined by the quadratic model of CCD in this study to obtained $89.42 \% \mathrm{DH}$ were $2.85 \% \mathrm{v} / \mathrm{w}$ Alcalase concentration at $\mathrm{pH} 8.48$ for 27.18 minutes of hydrolysis time as $61^{\circ} \mathrm{C}$. In terms of $\mathrm{pH}$ and temperature, the results in this present study are in accordance with the results of study of Yuan et al., 2008 [18] showing Alcalase 2.4 L exhibited the highest values in terms of $\mathrm{DH}$ when optimum temperature at $60{ }^{\circ} \mathrm{C}, \mathrm{pH}$ 8.0 with high protein yield up to $80.33 \%$. Figure 1 shows the respective response surface plots (3-D). These plots illustrate the significant interaction of the two independent variables to determine the optimum conditions for enzymatic hydrolysis in this study. Figure1A shows the effect of temperature and reaction time on DH. Results showed DH increased as time and temperature increased. When the reaction temperature increased from $50{ }^{\circ} \mathrm{C}$ to $60{ }^{\circ} \mathrm{C}$, the $\mathrm{DH}$ significantly increased from $20 \%$ to $89 \%$.

The reaction temperature has a significantly impact on the $\mathrm{DH}$ of this mixed fish species. However, by further increasing the reaction temperature to $70^{\circ} \mathrm{C}$, a decline in the DH observed. The reduction in the $\mathrm{DH}$ possibly resulted from the thermal denaturation of enzyme increased since the reaction shifted out from the optimum temperature, thus leading to a decrease in the $\mathrm{DH}$. In this production, $61^{\circ} \mathrm{C}$ was chosen as the optimum reaction temperature once all other influential parameters were kept in the ranges. Our results agree with Vannabun et al., 2014 [26] who characterized alkaline protease with optimal temperature at $60^{\circ} \mathrm{C}$ for hydrolysis the viscera of farmed giant catfish. From the result presented in Figure1B, the DH gradually increased with the increasing $\mathrm{pH}$ from 6 to 8.5. The obtained results agreed with the nature of enzyme activity of commercial Alcalase ${ }^{\circledR}$ which normally active between $\mathrm{pH} 6.5$ and 8.5. As a further increase in $\mathrm{pH}$ up to 10 , the $\mathrm{DH}$ gradually decreased within the time range of 10-30 min. However, the DH gradually increased to a plateau between 25 to 30 min reaction time resulting in the $\mathrm{DH}$ raised from $60 \%$ to $85 \%$ as in Fig.2A. The longer reaction time would allow Alcalase to act more extensively on the fish muscle, thus resulting in an increment in the DH as previously reported by Haslaniza et al., 2010 [27].
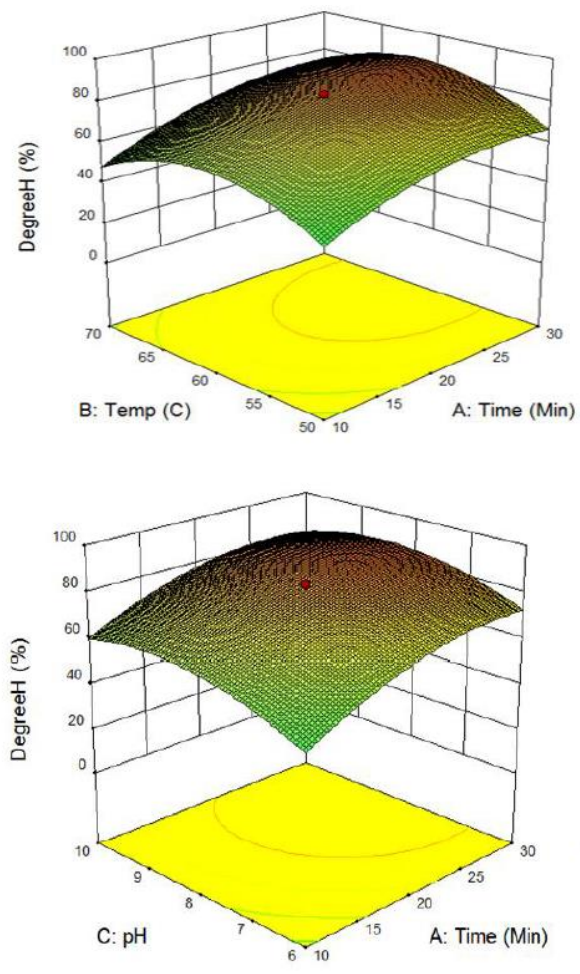

Fig.1. The 3-D surface plot of interaction between the parameters on degree of hydrolysis, (A) temperature and time, (B) $\mathrm{pH}$ and time.

However, the prolonging the reaction time beyond 25 min, no significant increase in DH occurred. Based on the obtained results, $27 \mathrm{~min}$ was selected as the suitable reaction time. The effect of $\mathrm{pH}$ and hydrolysis temperature on DH was shown in Fig. $2 \mathrm{~B}$, the $\mathrm{DH}$ was increased $25 \%$ to $89 \%$ as the $\mathrm{pH}$ increased from 6 to 8.5 . However, by further increasing $\mathrm{pH}$ to 10 , an obvious decrease in the $\mathrm{DH}$ was detected once temperature exceed to $70{ }^{\circ} \mathrm{C}$. The effect of enzyme concentration on the DH displayed in Fig.2C. The DH of hydrolysates was insignificantly $(p=0.7740)$ increased when enzyme concentration was increased from $2.0 \%$ to $4.0 \%$ at a fixed temperature. As temperature gradually increased from 50 to $60{ }^{\circ} \mathrm{C}$ at $2 \%$ enzyme concentration, $\mathrm{pH} 6.0$ resulting in the DH raised from $48 \%$ to $73 \%$. However, by extending the reaction temperature to $70{ }^{\circ} \mathrm{C}$, a decline in the DH was observed. The influence of enzyme concentration and $\mathrm{pH}$ change on the $\mathrm{DH}$ accessed within the same range as previously discussed and the results 
displayed in Fig 2D.Results showed that the DH was slightly increased from 70 to $83 \%$ when $\mathrm{pH}$ gradually increased from 6 to 8.5 and slightly decreased to $79 \%$ when the $\mathrm{pH}$ reach to 10 .
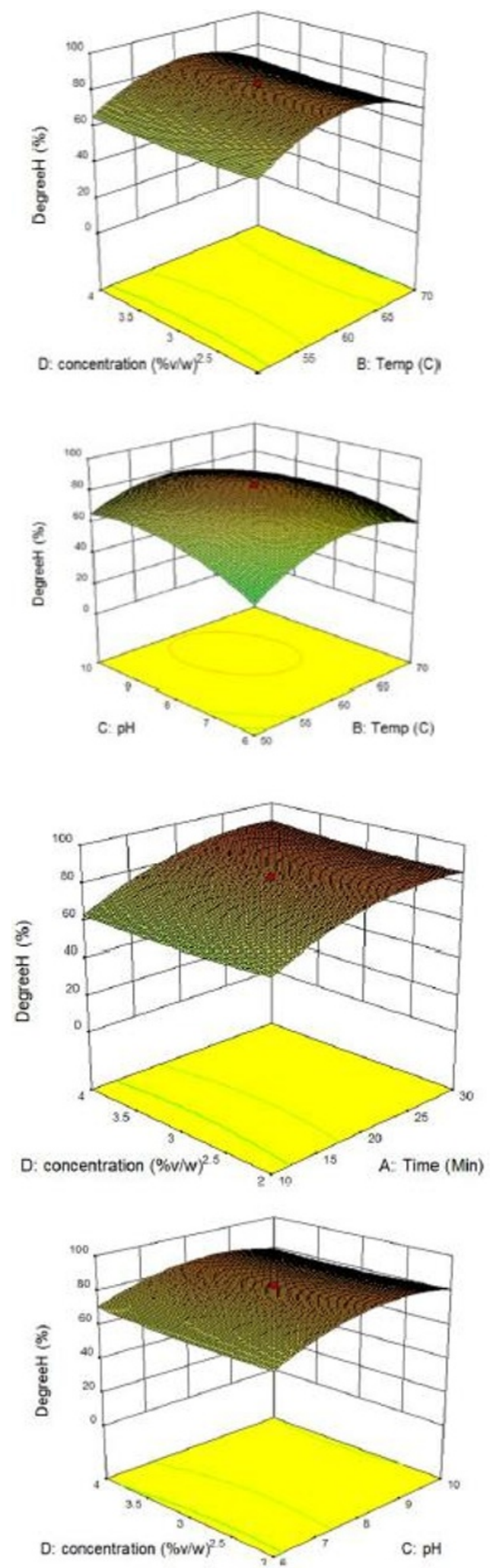

Fig.2. The 3-D surface plot (A) enzyme concentration and time, (B) $\mathrm{pH}$ and hydrolysis temperature, (C) enzyme concentration and temperature and (D) enzyme concentration and $\mathrm{pH}$.

\subsection{Validation the CCD model of FPH}

In order to validate the statistical optimization of hydrolysis conditions of Alcalase on mixed fish towards degree of hydrolysis using response surface design. The validation experiments for confirming the adequacy of model was attempted for the accuracy of the model. The validation of the model performed under the optimum conditions in triplicate and found good agreement of DH as $78.27 \%$ obtained from the model prediction value of $89.42 \%$. The difference between the predicted and experimental value was $11.16 \%$. The difference of DH was a little higher than $10 \%$ enough to justify the validity of the response model with the high degree of accuracy leading to the hydrolysis yield.

\subsection{Criteria of bioprocess operation}

FSH production in this study can be manipulated the condition according to the criteria of process in terms of reaction speed, operation temperature, $\mathrm{pH}$ and enzyme concentration in order to obtain the desired product under the constrain condition or lowest operation cost [28]. We would suggest the following conditions to produce the FPH to make the hydrolysis process more controllable as the following four conditions. Firstly, in order to minimize the hydrolysis time and maximize degree of hydrolysis while temperature, $\mathrm{pH}$ and enzyme concentration kept in range of this experiment, the FPH production could be carried out at $65.58 \% \mathrm{DH}$ using $3.74 \% \mathrm{v} / \mathrm{w}$ of enzyme concentration at $59.72^{\circ} \mathrm{C}, \mathrm{pH} 8.72$ for $10 \mathrm{~min}$. Secondly, an alternative process can be done if the consideration focus on minimizing the hydrolysis temperature and maximization of degree of hydrolysis while $\mathrm{pH}$, enzyme concentration and time were kept in range of this study. FSH can be produced with $71.73 \%$ $\mathrm{DH}$ by using $2.38 \% \mathrm{v} / \mathrm{w}$ of enzyme concentration at 50 ${ }^{0} \mathrm{C}$, $\mathrm{pH} 9.08$ for $25.86 \mathrm{~min}$. Thirdly, to minimize the $\mathrm{pH}$ and maximize $\mathrm{DH}$ with maintaining time, temperature and enzyme concentration in range of this study, the FPH production could run to obtain $75.53 \% \mathrm{DH}$ using $2.90 \% \mathrm{v} / \mathrm{w}$ of enzyme at $62.88{ }^{\circ} \mathrm{C}, \mathrm{pH} 6.00$ for 28.09 min. For final option of operation process, it required $3.15 \% \mathrm{v} / \mathrm{w}$ of enzyme loading at $60.83{ }^{\circ} \mathrm{C}$, pH 8.49 for $27.18 \mathrm{~min}$ of operation time. This option would resulting in the $\mathrm{DH}$ of $89.42 \%$.

\subsection{Proximate composition}

Result of proximate analysis revealed that protein content was relatively the same between FSH $(87.11 \%)$ and dry weight powder of mixed fish raw material (87.11\%) as depicted in Table 5. The freezed-dried FSH produced from this experiment was a brownish powder with fishy smell. The hydrolytic process of minced fish raw material by enzyme could generate molecules ranging from smaller proteins, peptides and individual amino acid. This FSH was then characterized molecular distribution through the sequential membrane filtration. Result showed the smaller size proteins in range of 30 $100,10-30,5-10,3-5,1-3$ and $<1 \mathrm{kDa}$ of $7.35,10.36$, $10.24,25.62$ and $46.43 \%$, respectively. Fractionation of 
FSH especially $<1 \mathrm{kDa}$ has a great potential to explore for bioactive peptides such as antioxidant activity, Angiotensin-Converting Enzyme inhibitor activity and hypocholesterolemic activity. However, the higher sizes of FSH are also attract the interest to find the capacity of food and feed application in terms of emulsifying properties, water-holding capacity and foaming capacity.

Table 5. Proximate chemical composition of mixed fish raw material and freezed-dried fish protein hydrolysate.

\begin{tabular}{|l|c|c|c|}
\hline $\begin{array}{c}\text { Componen } \\
\text { ts }(\%)\end{array}$ & Wet weight & Dry weight & FPH \\
\hline Moisture & $77.92 \pm 0.95$ & - & $5.03+0.78$ \\
\hline Protein & $15.70 \pm 0.47$ & $87.11 \pm 2.28$ & $88.61+2.81$ \\
\hline Lipid & $2.56 \pm 0.07$ & $8.83 \pm 0.65$ & $1.30+0.05$ \\
\hline Ash & $2.74 \pm 0.11$ & $3.06 \pm 0.15$ & $5.06+0.15$ \\
\hline
\end{tabular}

\subsection{Amino acid composition}

The composition of amino acid in freezed dried FPH is presented in Table 6. The major amino acids in FPH were glutamine, asparagine and lysine, respectively. To evaluate the nutritional properties of $\mathrm{FPH}$, the chemical score was calculated in comparision with FAO/WHO and NRC standard protein $[29,30]$. The results indicated that the nutritional value of FPH are less than both standard almost all amino acid except histidine and lysine in reference protein 1 . However, a large proportion of total amino acid normally occurs in short chain peptides proven to benefit for FPH production in aqafeed. The essential amino acid makes up $30.84 \%$ of all amino acids. The hydrolysates contain enough content of the flavor enhancers, glutamic acid, asparagine, alanine by $24.56 \%$ of the total amino acids, which account for the good taste.

For nutritional applications, it is important to gain a high DH in protein hydrolysates to boost the absorption in digestive tract of animal digestion. The nutritional quality in terms of amino acid composition comparison between the experiments and the report values of fish meal and soy bean meal as previously investigation by Swanepoel and Goosen [31] shown in Table 7. Results showed the amount of EAA in the FSH was $292.6 \mathrm{~g} / \mathrm{kg}$ total amino acid which was lower than those of fish and soybean meal by 1.62 and 1.48 times. All EAA were present in FPH with the leading amount amino acids as lysine, leucine and threonine except for tryptophan. Tryptophan is an acid labile amino acid destroyed during acid hydrolysis for sample preparation [31]. For nonessential amino acid (NEAA) results was found that glutamic acid was the most abundant amino acid present in freeze died FSH followed by aspartic acid as shown in Table 7.

Results showed the amount of EAA in the FSH was $292.6 \mathrm{~g} / \mathrm{kg}$ total amino acid which was lower than those of fish and soybean meal by 1.62 and 1.48 times. All EAA were present in FPH with the leading amount amino acids as lysine, leucine and threonine except for tryptophan. Tryptophan is an acid labile amino acid destroyed during acid hydrolysis for sample preparation [32].
Table 6. Composition of amino acids and chemical score.

\begin{tabular}{|c|c|c|c|c|c|}
\hline \multirow[t]{2}{*}{ Amino acids } & \multirow{2}{*}{$\begin{array}{l}\text { Amount } \\
(\mathrm{g} / 100 \mathrm{~g} \\
\text { proteins) }\end{array}$} & \multirow{2}{*}{$\begin{array}{c}\text { Ref. } \\
\text { Protei } \\
\mathrm{n} 1^{\mathrm{a}}\end{array}$} & \multirow{2}{*}{$\begin{array}{l}\text { Ref. } \\
\text { Prote } \\
\text { in } 2^{\text {b }}\end{array}$} & \multicolumn{2}{|c|}{ Chemical score } \\
\hline & & & & RP-1 & RP-2 \\
\hline \multicolumn{6}{|c|}{ Essential amino acids } \\
\hline Histidine & 2.25 & 2.00 & 2.10 & 1.13 & 1.07 \\
\hline Threonine & 3.15 & 4.00 & 3.90 & 0.79 & 0.81 \\
\hline Arginine & 4.27 & 5.00 & 1.31 & 0.85 & 3.26 \\
\hline Tyrosine & 1.58 & - & - & - & - \\
\hline Valine & 2.66 & 5.42 & 3.60 & 0.49 & 0.74 \\
\hline Methionine & 1.95 & 3.50 & 3.10 & 0.56 & 0.63 \\
\hline Phenylalanine & 2.47 & 4.29 & 6.50 & 0.58 & 0.38 \\
\hline Isoleucine & 2.24 & 4.00 & 2.50 & 0.56 & 0.90 \\
\hline Leucine & 4.72 & 7.00 & 3.30 & 0.67 & 1.43 \\
\hline Lysine & 5.55 & 5.50 & 5.70 & 1.01 & 0.97 \\
\hline \multicolumn{6}{|c|}{ Non-Essential amino acids } \\
\hline Asparagine & 6.21 & & & & \\
\hline Glutamine & 10.26 & & & & \\
\hline Serine & 2.71 & & & & \\
\hline Glycine & 3.74 & & & & \\
\hline Alanine & 4.35 & & & & \\
\hline Cysteine & 0.41 & & & & \\
\hline Proline & 2.56 & & & & \\
\hline$\Sigma$ AAs & 61.08 & & & & \\
\hline$\Sigma$ EAAs & 30.84 & & & & \\
\hline$\Sigma \mathrm{N}-\Sigma \mathrm{AAs}$ & 30.24 & & & & \\
\hline $\begin{array}{l}\Sigma \text { EAAs/ } \Sigma \text { AAs } \\
(\%)\end{array}$ & 50.49 & & & & \\
\hline $\begin{array}{l}\Sigma \mathrm{EAAs} / \Sigma \mathrm{N}- \\
\sum \mathrm{AAs}\end{array}$ & 1.02 & & & & \\
\hline
\end{tabular}

${ }^{a}$ Reference protein 1: Essential amino acid reference protein according to FAO/WHO (1985) [28]

${ }^{b}$ Reference protein 2: Essential amino acid requirement of common carp according to NRC (1993) [29]

For non-essential amino acid (NEAA) results was found that glutamic acid was the most abundant amino acid present in freeze died FSH followed by aspartic acid as shown in Table 7. This results of high levels of nonessential amino acid as glutamic and aspartic acid was similar to several reports from previous study [4, 3337]. Chemical composition of FPH is important in both nutrition perspective of human health. Our amino acid profile results are in the same range of several reports on the chemical composition of FPH that are prepared from various fish protein sources [33-37]. Chemical composition of FPH is important in both nutrition perspective of human health. Our amino acid profile results are in the same range of several research documents have been reported the chemical composition of FPH that are prepared from various fish protein sources. These reports included catfish (Clarias gariepinus) [31], bluewing searobin (Prionotus punctatus) [36] and Misgurnus anguilliacaudatus [37]. According to Watford report [38], some non-essential amino acids (like glutamic acid), presented an important role in the maintaining optimal health and growth levels.

\section{Conclusion}

Alcalase concentration at $2.85 \%(\mathrm{v} / \mathrm{w}), \mathrm{pH} 8.45$ for 27 min. incubation time as $61^{\circ} \mathrm{C}$ were the potential optimum conditions that gave the highest $\mathrm{DH}$ of $78.27 \%$ to produce FSH. The experimental data obtained based on the optimized conditions was in close agreement with 
the RSM model prediction. Four alternative conditions through RSM approach of optimization have a promising for FPH production in the future. In addition, the potential of this improved approach in the present study is affording a method for the efficiency of production process, which may be beneficial for reducing enzymatic loading and hydrolysis temperature leading to reduction of raw material for production and energy costs. The implementation of optimization report is appropriate for FPH in pilot scale and further study of bioactive compounds in feed and nutraceutical application.

Table 7. Amino acid composition comparison

\begin{tabular}{|c|c|c|c|}
\hline \multirow[b]{2}{*}{ Amino acid } & \multicolumn{3}{|c|}{ Feed ingredients ( $\mathrm{g} / \mathrm{kg}$ total amino acids) } \\
\hline & $\begin{array}{c}\text { Fish } \\
\text { protein } \\
\text { hydrolysate }\end{array}$ & $\begin{array}{c}\text { Fish } \\
\text { meal }^{\mathrm{a}}\end{array}$ & $\begin{array}{c}\text { Soybean } \\
\text { meal }^{\text {b }}\end{array}$ \\
\hline Arginine & 42.7 & 65.4 & 81.3 \\
\hline Histidine & 22.5 & 19.5 & 33.7 \\
\hline Isoleucine & 22.4 & 34.6 & 39.7 \\
\hline Leucine & 47.2 & 77.7 & 75.9 \\
\hline Lysine & 55.5 & 101.7 & 30.5 \\
\hline Methionine & 19.5 & 44.6 & 8.6 \\
\hline Phenylalanine & 24.7 & 39.8 & 79.2 \\
\hline Threonine & 31.5 & 44.4 & 40.4 \\
\hline Tryptophan ${ }^{1}$ & ND & ND & ND \\
\hline Valine & 26.6 & 46.6 & 43.6 \\
\hline$\sum$ EAA & 292.6 & 474.3 & 432.9 \\
\hline Alanine & 43.5 & 65.2 & 43.6 \\
\hline Aspartic acid & 62.1 & 103.9 & 109.7 \\
\hline Glutamic acid & 102.6 & 154.2 & 182.5 \\
\hline Glycine & 37.4 & 66 & 57.9 \\
\hline Proline & 0 & 50.4 & 64 \\
\hline Serine & 27.1 & 48.5 & 52.4 \\
\hline Tyrosine & 0 & 37.6 & 57 \\
\hline$\sum$ NEAA & 15.8 & 525.8 & 567.1 \\
\hline
\end{tabular}

a,b Amino acid composition of principle protein ingredients in the diets from Swanepoel and Goosen, 2011[30]

\section{Acknowledgement}

Author are indebted to a financial grant from KMUTNB-GOV59-35.The author also would like to thank INTEQC Group., Co Ltd, Thailand for raw material and initiation to implement the fish protein hydrolysate production.

\section{References}

1. I. Richter, J. Thøgersen, C.A. Klöckner, Sustainable seafood consumption in action : relevant behaviors and their predictors, Sustainability, 9 (2017): 1-19

2. S. I. Aspmo, S. J. Horn, V. G.H. Eijsink, Hydrolysates from Atlantic cod (Gadus morhua L.) viscera as components of microbial growth media, Process Biochemistry, 40 (2005): 3714-3722

3. O. Martínez-Alvarez, S. Chamorro, A. Brenes, Protein hydrolysates from animal processing byproducts as a source of bioactive molecules with interest in animal feeding: A review, Food Research International, 73 (2015): 204-212

4. M. Chalamaiah, B. Dinesh Kumar, R. Hemalatha, T. Jyothirmayi, Fish protein hydrolysates: proximate composition, amino acid composition, antioxidant activities and applications: a review, Food Chemistry, 135 (2012): 3020-3038

5. M. Chalamaiah, W. Yu, J. Wu, Immunomodulatory and anticancer protein hydrolysates (peptides) from food proteins: A review, Food Chemistry, 245 (2017): 205-222

6. P.J. García-Moreno, I. Batista, C. Pires, N. M. Bandarra, F. J. Espejo-Carpio, A. Guadix, and E.M. Guadix, Antioxidant activity of protein hydrolysates obtained from discarded Mediterranean fish species, Food Research International, 65 (2014): 469-476

7. N.A. Zakaria, N.M. Sarbon, Physicochemical properties and oxidative stability of fish emulsion sausage as influenced by snakehead (Channa striata) protein hydrolysate, LebensmittelWissenschaft \& Technologie, 94 (2018): 13-19

8. O. Villamil, H. Váquiro, J. F. Solanilla, Fish viscera protein hydrolysates: Production, potential applications on functional and bioactive properties, Food Chemistry, 224 (2017):160-171

9. A. Noman, Y. Xu, W. Q., AL-Bukhaiti, S. M., Abed, A. H., Ali, A. H., Ramadhan, W. Xia, Influence of enzymatic hydrolysis conditions on the degree of hydrolysis and functional properties of protein hydrolysate obtained from Chinese sturgeon (Acipenser sinensis) by using papain enzyme, Process Biochemistry, 67 (2018): 19-28

10. F. Alavi, M. Jamshidian, K. Rezaei, Applying native proteases from melon to hydrolyze kilka fish proteins (Clupeonella cultriventris caspia) compared to commercial enzyme Alcalase, Food Chemistry, 277 (2019): 314-322

11. M.S. Benhabiles, N. Abdi, N. Drouiche, H. Lounici, A. Pauss, M.F.A. Goosen, N. Mameri, Fish protein hydrolysate production from sardine solid waste by crude pepsin enzymatic hydrolysis in a bioreactor coupled to an ultrafiltration unit, Materials Science and Engineering: C, 32 (2012): 922-928

12. O. Villamil, H. Váquiro, J. F. Solanilla, Fish viscera protein hydrolysates: Production, potential applications and functional and bioactive properties, Food Chemistry, 24 (2017): 160-171

13. N.R.A. Halim, H.M. Yusof, N.M. Sarbon, Functional and bioactive properties of fish protein hydolysates and peptides: A comprehensive review, Trends in Food Science and Technology, 51 (2016): 24-33

14. H.C. Tran, H.A.T. Le, T.T. Le, V.M. Phan, Effects of enzyme types and extraction conditions on protein recovery and antioxidant properties of hydrolysed proteins derived from defatted Lemna minor, Applied Science and Engineering Progress, (2021) doi: 10.14416/j.asep.2021.05.003

15. T. Aspevik, H. Egede-Nissen, Ĺ. Oterhals, A systematic approach to the comparison of cost efficiency of endopeptidases for the hydrolysis of Atlantic salmon (Salmo salar) by-products. Faculty of Food Technology and Biotechnology. 54 (2016): 421-431 
16. A.M. Liceaga-Gesualdo, E.C.Y Li-Chan, Functional properties of fish protein hydrolysate from Herring (Clupea harengus). Journal of Food Science, 64 (1999): 1000-1004

17. H.G. Kristinsson, B.A. Rasco, Fish protein hydrolysates: Production, biochemical and functional properties. Critical Reviews in Food Science and Nutrition, 40 (2000): 43-81

18. X. Yuan, X. Gu, J. Tang, Optimization of the production of Momordica charantia L. Var. abbreviata Ser. protein hydrolysates with hypoglycemic effect using Alcalase, Food Chemistry, 111 (2008): 340-344

19. T. P. Singh, R. A. Siddiqi, D. S. Sogi, Statistical optimization of enzymatic hydrolysis of rice bran protein concentrate for enhanced hydrolysate production by papain, Lebensmittel-Wissenschaft \& Technologie, 99 (2019): 77-83

20. D. Betancur-Ancona, R. Martinez-Rosado, A. Corona-Cruz, A. Castellanos-Ruelas, M.E. Jaramillo-Flores, L. Chel-Guerrero, Functional properties of hydrolysates from Phaseolus lunatus seeds, International Journal of Food Science and Technology, 44 (2009): 128-137

21. N. Bhaskar, T. Benila, C. Radha, R.G. Lalitha, Optimization of enzymatic hydrolysis of visceral waste proteins of Catla (Catla catla) for preparing protein hydrolysate using a commercial protease, Bioresource Technology, 99 (2008): 335-343

22. K. Zhang, B. Zhang, B. Chen, L. Jing, Z. Zhu, K. Kazemi, Modeling and optimization of Newfoundland shrimp waste hydrolysis for microbial growth using response surface methodology and artificial neural networks, Marine Pollution Bulletin, 109 (2016): 245-252

23. J. Adler-Nissan, Determination of the degree of hydrolysis of food proteins hydrolysates by Trinitrobenzenesulfonic acid, Journal of Agricultural and Food Chemistry, 27 (1979):12561262

24. N. Wisuthiphaet, S. Klinchan, S. Kongruang, Fish Protein Hydrolysate Production by Acid and Enzymatic Hydrolysis, Applied Science and Engineering Progress, 9 (2016): 261-270

25. M.A. Amiza, S. Nurul Ashikin, A.L. Faazaz, Optimization of enzymatic protein hydrolysis from silver catfish (Pangasius sp.) Frame, International Food Research Journal, 18 (2011): 775-781

26. A. Vannabun, S. Ketnawa, S. Phongthai, S. Benjakul, S. Rawdkuen, Characterization of acid and alkaline proteases from viscera of farmed giant catfish, Food Bioscience, 6 (2014): 9-16
27. H. Haslaniza, M.Y. Maskat, W.M. Wan Aida, S. Mamot, The effects of enzyme concentration, temperature and incubation time on nitrogen content and degree of hydrolysis of protein precipitate from cockle (Anadara granosa) meat wash water, International Food Research Journal, International Food Research Journal, 17 (2010): 147-152

28. V.Venugopal, Enzymes from seafood processing waste and their applications in seafood processing, in Advances in Food and Nutrition Research, S.-K. Kim and F. Toldrá, Academic Press, 78 (2016): 4769

29. FAO/WHO, Energy and protein requirements, Report of joint FAO/WHO/UNU Expert Consultation Technical Report. FAO/WHO and United Nations University, Geneva, 724 (1985): 116-129

30. NRC National Research Council, Nutrient Requirement of Fish, National Academy of Science Washington, (1993): 124.

31. J.C. Swanepoel, N.J. Goosen, Evaluation of fish protein hydrolysates in juvenile African catfish (Clarias gariepinus) diets, Aquaculture, 496 (2018): 262-269

32. S. MacKenzie, Recent developments in amino acid analysis by gas-liquid chromatography, in Methods of biochemical analysis, D. Glick, Ed. John Wiley and Sons, 27 (2009): 1-88

33. S. Benjakul, M.T. Morrissey, Protein hydrolysates from pacific whiting solid wastes, Agricultural and Food Chemistry, 45 (1997): 3423-3430

34. S.F. See, L.L. Hoo, A.S. Babji, Optimization of enzymatic hydrolysis of Salmon (Salmo salar) skin by Alcalase, International Food research, 18 (2011): 1359-1365

35. H. Yin, J. Pu, Y. Wan, B. Xiang, P.J. Bechtel, S. Sathivel, Rheological and functional properties of Catfish skin protein hydrolysates, Journal of Food Science, 75, 1 (2010): E11-E17

36. S.A., Santos, V.G. Martins, M. Salas-Mellado, C. Prentice, Evaluation of functional properties in protein hydrolysates from Bluewing Searobin (Prionotus punctatus) obtained with different microbial enzymes, Food and Bioprocess Technology, 4 (2011): 1399-1406

37. L. You, M. Zhao, J. M. Regenstein, and J. Ren, In vitro antioxidant activity and in vivo anti-fatigue effect of loach (Misgurnus anguillicaudatus) peptides prepared by papain digestion, Food Chemistry, 124 (2011): 188-194

38. M. Watford, Glutamine and glutamate: Nonessential or essential amino acids?" Animal Nutrition, 1 (2015): 119-122 